\title{
INTERNATIONALIZATION: A NEW CHALLENGE FOR MILITARY UNIVERSITIES Rudolf URBAN
}

\author{
University of Defence, Brno, Czech Republic, ubn17@centrum.cz
}

\begin{abstract}
The paper attempts to show the development within the education of military professionals in the context of new challenges. It focuses on not only the general evolution of education but also on internationalization as an important element to increase the necessary quality of military professional training. Readers can find explanation of the advantages of international terms as a common instrument that would create future possibilities for cooperation among military universities.
\end{abstract}

\section{Keywords: military professionals' education, internationalization, cooperation}

\section{Introduction}

Internationalization is a term being used more and more to discuss the international dimension of higher education, and more widely postsecondary education. It is a term that means different things to different people and is thus used in a variety of ways. While it is encouraging to see the increased use and attention being given to internationalization, there is a great deal of confusion about exactly what it means. For some, it means a series of international activities such as academic mobility for students and teachers; international linkages, partnerships and projects; new international academic programs and research initiatives. For others, it means the delivery of education to other countries through new types of arrangements such as branch campuses or franchises, and using a variety of face-to-face and distance learning techniques. To many, it means the integration of an international, intercultural and/or global dimension into the curriculum and teaching learning process [1]. Military higher education institutions - universities have recently undergone changes in quality characterised primarily by the effort of being ranked a fully acknowledged partner in national education systems and by meeting the requirement of holding accredited degree study programmes. An important parameter of accredited studies implementation quality is the opportunity of becoming an Erasmus Charter holder and thus the opportunity of using the allocated financial resources supporting international mobility as a most important element of internationalization. It is a key resource for many military universities to be able to implement teachers/students mobility of various lengths of duration.

With the acceptation of the new qualitative requirement in mind it is possible to say that the military education system has also turned harmonised primarily in the European space as it has started to use the same tools and education quality indicators as the civilian one. European general education policy keeps raising the stipulated demands concerning the requirements of implementing internationalization into the national education systems. 
Generally it is based on the idea that "All students will live in a globalized world, as professionals and citizens, and this is a common rationale for integration". The higher education institutions should hold in line with the idea by recalling that "Internationalisation of the curriculum is the incorporation of an international and intercultural dimension into the content of the curriculum as well as the teaching, learning and assessment arrangements and support services of a programme of study"'[2].

2. Tertiary education institutions' key priorities toward internationalization from EU's point of view

Internationalization's global strategy should comprise the key areas belonging to the following three categories: student/staff international mobility; internationalization and improvement of study programmes and digital learning; strategic cooperation, partnership and capacity building. Rather than separately, the categories should be viewed as fix elements of the comprehensive strategy with the content options as follows [3]:

1. Student/staff international mobility support should include:

- improvement of tertiary education through mobility, while the improvement means learning new competences, language skills, adopting new teaching methods and building international networks,

- two-way mobility with non-EU nations,

- encouragement of staff and student to engage in mobility,

- improved service to the sent/received students/researchers

2. Internationalization process support at home and digital learning should define an appropriate level and structure of international mobility both for the staff and for the students. Benefits from internationalization should be broader than for the minority of students or staff who spend certain period of time abroad. That primarily means:
- form the structure of study fields so that teaching and education process can get an international dimension,

- support also other language training then only English,

- contribution by international teachers/researchers and participation of international students with international experience/attitude are an opportunity for the students who has not been sent from their home institution to learn the international methods.

3. Building strategic cooperation, partnership and capacities should comprise the following:

- accreditation of joint and double degree programmes,

- establishing and building strategic partnerships among universities as well as between universities and enterprises,

- cooperation with less developed countries.

The situation of the internationalization of higher education institutions' activities in relation to the above declared priorities generally lacks the desired level. That fact was mentioned by the Communication on a strategy for the internationalisation of higher education (2011) with the following comments:

- only a few highly visible universities have a real internationalisation strategy;

- universities do not have a choice between going international or staying local: they must have an international strategy;

- only a few highly visible universities have developed a comprehensive internationalization;

- most universities have not yet adopted a clear international line and tend to have a fragmented international approach, usually based on individual initiatives rather than on a clearly defined institutional strategy;

Improvements in such a situation are expected to result from the launched 
Erasmus + project that open space for a vast cooperation of the universities in three different areas with the following key activities:

- KA 1 - mobility in (formal and informal) education for individuals - credited mobility,

- KA 2 - cooperation in innovations and exchange of best practices, such as strategic partnerships, collaboration of schools on teaching-oriented projects or joint study programmes of universities;

- KA 3 - supporting the reforms in education policy (including thirdcountries cooperation), such as improved teaching methods in the international cooperation among universities.

\section{Young NATO officer education essential requirements}

Education of new officers should comply with the intellectual development of a professional deployable in contemporary multinational operations. Thus, the education integrating element should become a commonly accepted standard of knowledge and competence that would allow cooperation within the international staff/unit environment. Now, the essential idea of integrating education within the NATO is declared as follows: Connected Forces through Connected Education.

What are the expectations?

Connected Education promotes a collaborative and pragmatic approach to meet Alliance's requirements effectively. Connected Education includes but is not limited to the very best of contemporary professional education in four basic elements: educated minds-knowledge; skills and competency base; learning goals and methods; and improved exploitation of technology. In this context, CE is seen as a network of defence academies working with Strategic Commands and able to generate and share critical knowledge to all stakeholders and partners.

In result, the primary goal of CE should be towards improving the readiness of the military professionals to be successful, and to ensure that the military forces that they command are better connected through intellectual interoperability [4].

The above mentioned requirement clearly corresponds with goals of internationalisation struggling to establish a common education platform as a joint or double degree study programmes. The question is: how can be the mentioned expectations meet? What should be taken by universities?

Meeting the goals generally defined in the European education policy and by NATO schools' representatives will require the military universities to find the ways of harmonising their education strategies including the study programmes themselves that feature a number of national specific attributes seemingly unique reflecting the national professional attitudes rooted from national forces history and culture. The crucial requirement towards contemporary military professionals within NATO/EU forces is intellectual and expert interoperability. Such a personality profile may only be achieved through "connected education".

That is the substantial future challenge for military universities. The complexity of meeting the goal is determined by the reality of heterogeneous and specific military schools obliged to follow and in their graduates' profiles fulfil the military branch specialisation along with the general theoretical university degree requirements. Military branch specialisation seems to possibly turn in a risk and a limitation of integration and desired harmonised interoperability in producing new military officers.

The most serious threat to the integration process and forming the necessary space for a comprehensive internationalization is the time disharmony in overall studies duration (Bachelor's, Master's) while the time distribution over the terms with regard to syllabus and forms of education and training forms the core of the issue. Unlike civilian universities, the disharmony now 
prevents the military ones from full utilisation of Erasmus+ Programme opportunities and, consequently, from building and forming the comprehensive internationalisation system.

Achieving the goal of full-scale integration into national education systems completely accepting the Erasmus rules, the military universities need to mandatorily deal with meeting the internationalization requirements as an essential parameter of education quality.

3. Internationalization Requirements: New Challenges for Military Universities

The basic framework of internationalization as outlined in the European education policy consists of the following activities:

- student/teacher international mobility implementation and development to support education and research,

- "home" internationalization for the non-travelling teachers/students (presence of visiting professors / international students),

- exchange of information of education processes and public availability of the information (common information portals establishment),

- forming joint degree programmes on joint / double degree basis,

- establishment of strategic partnerships among military universities,

- imposing conditions for international research and scientific projects,

- internationalization of university administration and service background.

Internationalization represents a lengthy process of education quality development. Every university differs in the conditions and prerequisites for its meeting, usually influenced also by the requirements stipulated in the appropriate national policy. An example may be shown in the long-term requirement placed by the Czech Ministry of Education in the period 2016 - 2020 that defines in terms of internationalization for the universities, beside others, the following performance metric [5]:

1) At least 10 per cent of the graduates from Bachelor's and Master's degree programmes should be sent to an international scholarship/fellowship of the minimum length of two weeks.

2) At least 90 per cent of the graduates from doctoral degree programmes should be sent to an international academic trip while its length for at least 50 per cent of them should exceed one month.

$3)$ At least 3 per cent of degree programmes should be accredited as joint / double / multiple degree.

4) At least 3 per cent of graduates should graduate from the degree programmes accredited in other then Czech language.

With the above mentioned criteria in mind, it should be underlined here that the entire internationalization domain including additional activities supporting primarily teaching in foreign languages, creating international students friendly environment, integration of academic community international members (both students and teachers) into university's life, and others are evaluated within the accreditation process and thus have impact on granting the requested accreditation. University funding is expected to be interconnected with the level of meeting the internationalization criteria.

An important requirement conditioning the possibility of carrying out mobility is to reflect students' international stays in university study plans. International study stays should not intervene with or extend the time of standard studies duration. Therefore, the study plans need to schedule for involvement in a one or two-term long mobility programme. It is as well desirable to choose the partner institutions and study programmes so that the credits won / courses attended by the students may be accepted from the point of view of quality and subject similarity.

With regards to the above mentioned requirement, military universities will have 
to deal with the issue of theoretical education and, which is more serious, with practical training and professional preparation. Future will probably expect forming of "common modules" for both theoretical and practical training of military professionals so that a strategic partnership of several military universities allows arrangements of an "international term" that would meet the acceptable quality parameters of student mobility and winning the requested number of credit points. There are already activities in the European space intended to meet the questioned criteria. Events going on under the umbrella of strategic partnership of five military schools (in Austria, Czech Republic, Hungary, Poland and Romania) with a "trademark" of iMAF - International Military Academic Forum - may be considered an activity of that kind. Partial positive results are also generated within the consortium of military higher education schools associated in CEFME - Central European Forum on Military Education.

\section{Conclusion}

Military universities, with regard to the military profile of officers, have long paid attention to the issue of interoperability as well as to officers training for international deployments. However, till present time the activities were partial supporting primarily officers' training in the abilities of deployment abroad. A new requirement within NATO is defined in the implementation of a comprehensive attitude to officers' interoperability training, which definitely corresponds with the education comprehensive internationalization requirements supported and included in the EU education policy.

The key pool of interuniversity internationalization relationships forms on the basis of personal relations in the research, teaching and student communities. That implies it will depend on the universities themselves whether they will be able to define their own internationalization strategy that would support implementation of all of the already mentioned domains that should result in meeting the EU and NATO requirements.

The complexity of comprehensive internationalization implementation in military university situation exceeds in some parameters (sufficient funds allocation, defining common military internationalization strategy within EU, etc.) the responsibility and competences of the universities. The third key activity of Erasmus ${ }^{+}$programme universities may benefit from supposes there were projects, discussion fora, workshops that would support the debates oriented towards imposing the necessary conditions from the level of politicians and the highest military command for the military universities to meet the goals of comprehensive internationalization at both national and international levels.

\section{References}

[1] Knight J. International Handbook of Higher Education, Springer International Handbooks of Education, Volume 18, pp. 207-227, 2002

[2] Leask B. Internationalising the curriculum and all learning, Global edition, Issue No:347, 2014

[3] http://ec.europa.eu/education/higher-education/doc/com499_en.pdf Communication on a strategy for the internationalisation of higher education

[4] Conference of Commandants, NATO, Roma, 2014

[5] Ministry of education: Dlouhodobý záměr rozvoje VŠ 2016 - 2020, Praha. 2015 